\title{
Effect of Individual Factor on Entrepreneurship Intention among Undergraduate Students in Bhutan
}

\author{
Tashi Dendup (Corresponding author) \\ College of Natural Resources, Royal University of Bhutan \\ Tel: 975-1744-9139Ｅ-mail: tdup56@cnr.edu.bt \\ Indra Lal Acharja \\ Royal Thimphu College, Royal University of Bhutan \\ Tel: 975-1759-7655Ｅ-mail: emailindralal@gmail.com
}

Received: August 30, 2017 Accepted: September 17, 2017 Published: September 25, 2017 doi:10.5296/wjbm.v3i2.11779

URL: https://doi.org/10.5296/wjbm.v3i2.11779

\begin{abstract}
The study explored the effects of age; field of study, academic performance, and past job experience of undergraduate students under Royal University of Bhutan (RUB) on their entrepreneurial intention. Today, youth entrepreneurship is regarded as a career option. It is, therefore, important for the policymakers, educators, and the public to understand individual factors that influence to become entrepreneurs. This study collected data from 384 undergraduate students (sample size determined using Yamane formula) within the age group of 18-34 from four colleges under RUB using self-administrative structured questionnaires. To ensure representativeness in each selected college, it devised multi-stage proportionate sampling technique. This study conducted Chi-square test of independence to examine the influence of individual factors on their entrepreneurial intentions. The result showed that the academic course the student assumed and their past job experiences, especially in business has a relationship with their entrepreneurial career plan after graduation. Likewise, student's age influences their entrepreneurship intention. However, the result showed no relationship between academic performance and their entrepreneurial intentions after their graduation. Therefore, findings suggest the need for entrepreneurship education in the university curriculum.
\end{abstract}

Keywords: Bhutan, Entrepreneurial intention, Individual factors, Undergraduate students 


\section{Introduction}

Reducing youth unemployment is a major challenge for most of the government in the world (Schoof, 2006). In 2014, 13\% (73 million) of all young people were unemployed worldwide (Elder \& Rosas, 2015). Despite remarkable progress in other areas, Ministry of Labor and Human Resources (MOLHR) (2015) reported 2.5\% unemployment rate in Bhutan. The 2.5\% unemployment is low by international standard, but the concern is that youth unemployment rate had increased from $9.4 \%$ in 2014 to $10.7 \%$ in 2015. The level of unemployment in Bhutan is most likely to increase with the increasing number of graduates in the job market each year, the overstretched public sectors, and still developing private sectors. In such situation, where opportunities are limited, entrepreneurship is an option to reduce the unemployment and the associated problems (Fatoki, 2014).

Youth entrepreneurship not only reduces unemployment in the country but it also creates their destiny by starting companies, and they need not keep waiting for a job (Sharma \& Madan, 2014). Today, Bhutan believes that youth entrepreneurship is an innovative approach to integrate youngsters into the increasingly competitive labor market. However, as entrepreneurship is relatively a new concept in the country, there is need to understand the factors affecting entrepreneurial intentions of youngsters in Bhutan. Such findings will be useful for teachers, consultants, advisors, and policymakers to get a clearer picture of how individual's beliefs, perceptions, and motives influence the entrepreneurial intention (Wang, $\mathrm{Lu}, \&$ Millington, 2011). Hence, analyzing the effect of different factors on entrepreneurial intention among youths is of paramount importance to ensure relevant authorities to understand and duly support youth entrepreneurship in the country.

Definition of entrepreneurship is subject to debate since the evolution of concept in the early 1970s (Salami, 2011). Different scholars have interpreted it diversely depending on the nature and context of the study. Thus, due to lack of standard definition, this study adopted the definition of Reynolds (2005) assertion, where entrepreneurship means the discovery of opportunities and the subsequent creation of new economic activity. Youth in this study refers to the young people between the ages of 18 - 34 years as defined by Youth Business International (Kew, Herrington, Litovsky, \& Gale, 2013). Therefore, youth entrepreneurial intention in this study is understood as the likelihood of undergraduate students (aged 18-34 years old) to take-up a new economic activity or take over an existing one.

\subsection{Problem Statement}

According to MOLHR (2015), the agricultural farming employed 58\% of the population, followed by $19.1 \%$ in private businesses, and $7 \%$ in the civil service. However, the reluctance of educated youths in agricultural farming and private sectors makes civil service still the best choice. Utha et al. (2016) also reported prioritizing government jobs as the first option among Bhutanese students. Royal Civil Service Commission's decision to remain a small, compact and efficient organization has reduced vacancies to dozens of slots. Although government promotes the entrepreneurship, less number of start-ups by the youths indicates reluctance towards entrepreneurship. 
Despite all these facts, there is no clear understanding of the perception of young people towards entrepreneurship career decision, and the factors contributing or impeding their choice. The absence of such studies has created a dearth of reliable evidence on the subject matter. Thus, this information gap indicated the need for empirical evidence, to execute evidence-based interventions by the relevant authorities. Therefore, this study explored the effect of individual factors on entrepreneurial intentions among undergraduate students in Bhutan.

\subsection{Study Objectives}

To analyze the effect of individual factors such as age, field of study, academic performance, and job experience on the entrepreneurial intention of undergraduate students in Bhutan. To this end, this study proposed four hypotheses as follows:

$\mathrm{H}_{1}$ : The age of an individual influence entrepreneurial intention.

$\mathrm{H}_{2}$ : The field of study influence entrepreneurial intention.

$\mathrm{H}_{3}$ : The academic performance influence entrepreneurship intention.

$\mathrm{H}_{4}$ : The job experience in business influence entrepreneurial intention.

\section{Literature Review}

The previous researchers have considered individual factors such as age, field of study, academic performance, and job experience of students. For, example, Green (2013) found older individuals were more likely to be self-employed than younger ones. The same study also revealed that adults aged 15-24 years were more likely to be independent than teenagers aged 15-19 years old. Similarly, Stangler and Spulber (2013) also reported that higher levels of self-employment among older age groups than younger ones.

The several other researchers studied the influence of entrepreneurship education on entrepreneurial intention. For instance, Noel (2001) mentioned that students with entrepreneurship background have higher entrepreneurial intention and self-efficacy than students of other disciplines. Also, Kolvereid and Moen (1997) found graduates with an entrepreneurship major have stronger entrepreneurial intentions than other graduates. Similarly, other studies have also showed a significant relationship between entrepreneurship education and entrepreneurial career plan (Ekpoh \& Edet, 2011; Wilson, Kickul, \& Marlino, 2007).

There are works of literature on the influence of academic performance on entrepreneurship intentions. Suppose, Asoni (2011) found that formal college education does not play a significant role when it comes to entrepreneurship. Similarly, Van der Sluis, van Praag, and Vijverberg (2004) stated that higher levels of education might generate better opportunities in other sectors and thus, decrease the likelihood of creating a business. Kangasharju and Pekkala (2002) stated that educated individuals are less likely to prefer self-employment than uneducated ones. The argument was that the individual with higher qualification not only earn more but earning is secure as an employee than being an entrepreneur. Another study 


\section{Macrothink}

World Journal of Business and Management

ISSN $2377-4622$

2017, Vol. 3, No. 2

showed that compared to diploma and undergraduate students, entrepreneurial intention among postgraduate students are low as they face the high opportunity cost of time and stable cash flow demand ( $\mathrm{Wu} \& \mathrm{Wu}, 2008)$. These studies indirectly agree that those who score high academic marks have less entrepreneurial intention.

The earlier studies also considered the influence of job experience on entrepreneurial intention. A study by Kolvereid (1996) reported that people with business experience have higher entrepreneurial intention compared to those without it. Further, Fatoki (2014) found that previous exposure to business, role model, and networks have contributed towards becoming entrepreneurs. Besides, Drennan, Kennedy, and Renfrow (2005) illustrated that parental business experience and challenging childhood have a positive impact on starting one's own business. The individuals' past business experience influenced their decision-making and business performance (McStay, 2008). These reviews give a fair impression that previous job experiences in business affect the entrepreneurial intention.

However, due to differences in geography, economic conditions, and sociocultural factors, findings can vary from countries to countries. Thus, it is not wise to generalize the results from abroad, and applicability of those conclusions in Bhutan is questionable. Having said that there is lack of empirical studies on the subject matter in Bhutan. Therefore, there is need to understand the proposed research topic in the context of Bhutan to promote entrepreneurship culture in the country.

\section{Research Methodology}

\subsection{Theoretical Framework}

Depending on time and location, different scholars studied various factors affecting entrepreneurial intentions. As there is lack of a so-called standard model, this study developed a conceptual framework based on the literature review. This research framework shows the scope of the study and helped authors to test the proposed hypothesis in the context of Bhutan.

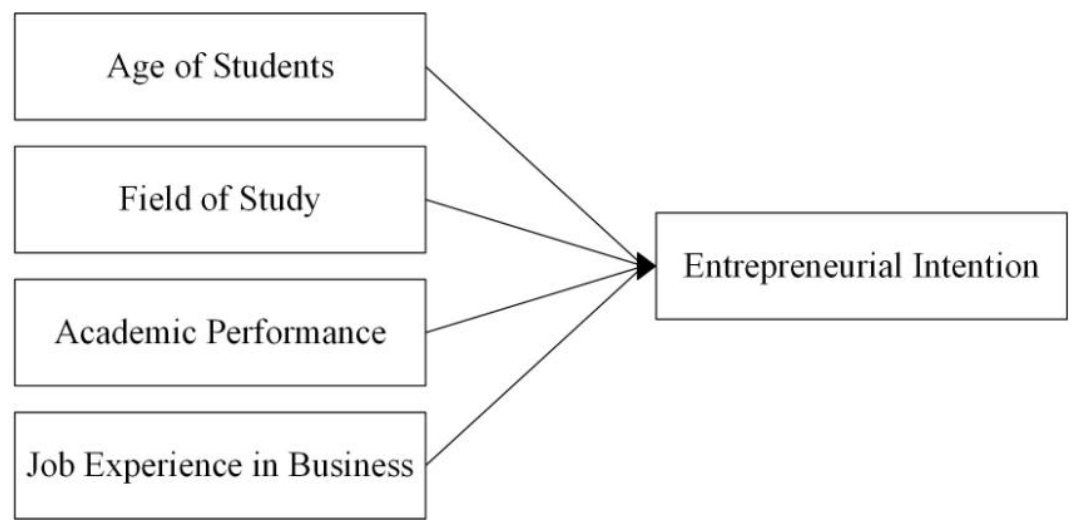

Figure 1. Theoretical framework 


\section{Ml Macrothink}

World Journal of Business and Management

ISSN 2377-4622

2017, Vol. 3, No. 2

\subsection{Data Collection and Analysis}

The target population for this study was the undergraduate students in nine colleges of RUB in 2016 (information accessed from Research Division, RUB). The sample of 384 was calculated using Yamane formula:

$$
n=\frac{\mathrm{N}}{1+\mathrm{Ne}^{2}}
$$

Where:

$$
\begin{aligned}
& \mathbf{N}=\text { Target population }(9,105) \\
& \mathbf{e}=\operatorname{Error}(5 \%) \\
& \boldsymbol{n}=\text { Sample size }
\end{aligned}
$$

The study employed the multi-stage random sampling to determine the sample colleges and the respondents. The first stage involved random selection of four out of nine colleges under RUB (lottery method). The College of Natural Resources, College of Science and Technology, Gaeddu College of Business Studies, and Sherubtse College were selected. The second stage involved random selection of students from sample colleges. Researchers randomly distributed questionnaires covering students of all departments. However, researchers applied proportionate sampling to get the representative sample in each selected college (see Table 1). Researchers collected data using pretested self-administered structured questionnaire. The survey questionnaire consisted of 22 questions that complete responding in 10 to 15 minutes. Authors used Microsoft Excel 2016 for data entry, coding, and cleaning. SPSS version 23 computed both descriptive analysis and Chi-square test of independence to determine the effect of individual factors on their entrepreneurial intentions.

Table 1. Sample colleges and proportionate sample size

\begin{tabular}{|l|c|c|}
\hline Selected Colleges & Population & Sample \\
\hline College of Natural Resources & 545 & 44 \\
\hline College of Science and Technology & 997 & 80 \\
\hline Gaeddu College of Business Studies & 1,481 & 119 \\
\hline Sherubtse College & 1,748 & 141 \\
\hline Total & 4,771 & 384 \\
\hline
\end{tabular}

\section{Results and Discussions}

\subsection{Sample Profile}

Table 2 presents the details of sample characteristics. Respondents constituted more men (58.1\%) than the woman (41.9\%). Commerce students $(31.8 \%)$ dominated the sample because Gaeddu College of Business Studies and Sherubtse College with maximum students has commerce program. The analysis also revealed that $64.6 \%$ of the students studied 
entrepreneurship module in their one or more semesters. Age category of the early $20 \mathrm{~s}(\geq 18$ to $\leq 25$ years old) and Later 20s ( $\geq 26$ to $\leq 34$ years old) was proposed to suit the purpose of this study. Age of students ranged from 20-31 years old with the mean age of $23( \pm 1.90)$. Only $13 \%$ of the students had business related part-time jobs, while many students $(31.8 \%)$ did their internship in government offices. This study also found that only $15.1 \%$ of students' fathers and $2.3 \%$ of students' mothers run the business. The fewer parents owning business show many students do not come from the business family. It means that there is a weak entrepreneurial culture in Bhutan. It also indicates the preferences of civil service over entrepreneurship by Bhutanese youths. On the same line, Utha et al. (2016) also reported that most Bhutanese students prefer government jobs. Most students (53.6\%) had their previous semester academic score between 60-69\%.

Table 2. Respondent's gender, the field of study and age category $(\mathrm{N}=384)$

\begin{tabular}{|l|l|c|}
\hline Variables & Categories & Frequency (Percentage) \\
\hline \multirow{4}{*}{ Gender } & Men & $223(58.1)$ \\
\cline { 2 - 3 } & Women & $161(41.9)$ \\
\hline \multirow{4}{*}{ Age of students of study } & Science & $89(23.2)$ \\
\cline { 2 - 3 } & Arts & $97(25.3)$ \\
\cline { 2 - 3 } & Commerce & $122(31.8)$ \\
\cline { 2 - 3 } & Engineering and Technology & $76(19.8)$ \\
\hline \multirow{5}{*}{ Student's part-time job } & Early 20s & $317(82.6)$ \\
\cline { 2 - 3 } & Later 20s & $67(17.4)$ \\
\hline & Constructions & $65(16.9)$ \\
\cline { 2 - 3 } & Business related & $52(13.0)$ \\
\cline { 2 - 3 } & Internship in government offices & $122(31.8)$ \\
\cline { 2 - 3 } & None & $145(37.8)$ \\
\hline & High $(\geq 70 \%)$ & $94(24.5)$ \\
\cline { 2 - 3 } & Average $(60-69 \%)$ & $206(53.6)$ \\
\cline { 2 - 3 } & Low $(\leq 59 \%)$ & $84(21.9)$ \\
\hline
\end{tabular}

\subsection{Student's Age and Entrepreneurial Intention}

Table 3 presents two age groups namely early 20 's ( $\geq 18$ to $\leq 25$ years old) and Later 20 s ( $\geq$ 26 to $\leq 32$ years old). The study calculated a Chi-square test of independence to compare the frequency of preferred profession after graduation and students age categories. Result showed a significant relationship between age category and entrepreneurial intentions $\chi^{2}(2, \mathrm{~N}=384)$ $=11.319, p=.003$. Relationship is further confirmed as chi-square calculated $(\chi 2$ calculated $=$ $11.391)$ is greater than Chi-square tabulated $(\chi 2$ tabulated $(2,0.05)=5.991$. More than half $(58 \%)$ of the student under the age category of later 20 s are more inclined toward being an entrepreneur after their graduation as compared to $36.6 \%$ of students under the age category of early 20s. The finding indicates that the age of the students influences their entrepreneurship career choice. Hence, the study accepted $\mathbf{H}_{\mathbf{1}}$ 'The age of an individual 
influence entrepreneurial intention' at 5\% level of significance. In agreement with the current finding Green (2013) also reported that the older people are more likely to be self-employed than the younger ones. Further, the Global Entrepreneurship Monitor observed males aged 50-64 years are about five times more likely to be independent than those aged 15-24 years (Schoof, 2006). The same study further illustrated that older ones aged 15-24 years are more likely to be self-employed than teenagers aged 15-19 years. However, the current study suggests entrepreneurship education start at an early age, with the curriculum developed at different levels of the education system. The argument here is that students will realize the accumulation of entrepreneurship knowledge and skills when nearing graduation. A study by Henley (2007) also tends to agree with the argument, which states that most people's intention to start new businesses are formed at least a year before the actual implementation.

Table 3. Cross tabulation of age group and job preference after graduation

\begin{tabular}{|l|c|c|c|c|}
\hline \multirow{2}{*}{ Age group } & \multicolumn{3}{|c|}{ Job preference after graduation } & \multirow{2}{*}{ Total } \\
\cline { 2 - 4 } & Civil servant & Entrepreneur & Corporate employee & \\
\hline Early 20's & 132 & 116 & 69 & 317 \\
\hline Later 20's & 16 & 39 & 12 & 67 \\
\hline Total & 148 & 155 & 81 & 384 \\
\hline
\end{tabular}

Table 4. Chi-square test result of age group and job preference after graduation.

\begin{tabular}{|l|c|c|c|}
\hline & Value & df & Asymp. Sig (2-sided) \\
\hline Pearson Chi-Square & $11.319^{\mathrm{a}}$ & 2 & .003 \\
\hline Likelihood Ratio & 11.301 & 2 & .004 \\
\hline Linear-by-Linear Association & 1.884 & 1 & .170 \\
\hline N of Valid Cases & 384 & - & - \\
\hline
\end{tabular}

a. 0 cells $(0.0 \%)$ have expected count less than 5. The minimum expected count is 14.13.

\subsection{Courses Studied and Entrepreneurial Intention}

The study involved students from the different field of studies including science, commerce, arts; and engineering and technology as shown in Table 5. The study used Chi-square test to determine the relationship between the field of study and profession after graduation. Table 6 indicates that there is a significant association between the area of study and profession after graduation $\chi^{2}(2, \mathrm{~N}=384)=32.678, \mathrm{p}=.000$. The relationship is further supported as $\chi 2$ tabulated $=32.678$ is greater than $\chi 2$ tabulated $(6,0.05)=12.592$. The result showed higher entrepreneurial intentions amongst students pursuing commerce $(57.4 \%)$ and arts $(42.3 \%)$ compared to science (31.5\%), and engineering and technology $(21 \%)$. Therefore, the study accepted $\mathbf{H}_{2}$ 'The field of study influence entrepreneurial intention' at 5\% level of significance. Higher entrepreneurial intentions amongst students with commerce and arts background are primarily due to more entrepreneurship-related courses in these two disciplines. Supporting the current result, Noel (2001) also reported that students with 
entrepreneurship knowledge scores high in entrepreneurial intention and self-efficacy than students of other disciplines. Various other studies in different settings have also shown that there is a significant relationship between entrepreneurship education and entrepreneurial career intention (Ekpoh \& Edet, 2011; Wilson et al., 2007). Another study by Fatoki (2014) also reported that students who studied business have a higher level of entrepreneurial intention. Further, Owusu-Ansah (2004) indicated that entrepreneurship education equips individuals with skills and competencies to initiate and run the businesses. As suggested by Schoof (2006), this study also suggests the need for integrating entrepreneurship education into university curriculum to impart appropriate entrepreneurial competencies and skills.

Table 5. Cross tabulation of the field of study and job preference after graduation

\begin{tabular}{|l|c|c|c|c|}
\hline \multirow{2}{*}{ Field of Study } & \multicolumn{3}{|c|}{ Job preference after graduation } & \multirow{2}{*}{ Total } \\
\cline { 2 - 4 } & Civil Servant & Entrepreneur & Corporate employee & \\
\hline Science & 39 & 28 & 22 & 89 \\
\hline Arts & 38 & 41 & 18 & 97 \\
\hline Commerce & 37 & 70 & 15 & 122 \\
\hline Engineering \& Technology & 34 & 16 & 26 & 76 \\
\hline Total & 148 & 155 & 81 & 384 \\
\hline
\end{tabular}

Table 6. Chi-Square Test result of field of study and job preference after graduation

\begin{tabular}{|l|c|c|c|}
\hline & Value & df & Asymp. Sig. (2-sided) \\
\hline Pearson Chi-Square & $32.678^{\mathrm{a}}$ & 6 & .000 \\
\hline Likelihood Ratio & 33.197 & 6 & .000 \\
\hline Linear-by-Linear Association & .526 & 1 & .468 \\
\hline N of Valid Cases & 384 & - & - \\
\hline
\end{tabular}

a. 0 cells $(0.0 \%)$ have expected count less than 5 . The minimum expected count is 16.03.

\subsection{Academic Performance and Entrepreneurial Intention}

Table 7 shows academic performance (average score of the past semester) categorized as high ( $\geq 70 \%$ ), average (60-69\%), and low $(\leq 59 \%)$. As shown in Table 8 , the study determines the relationship between academic performance and profession after graduation using Chi-square test of independence. The result showed no significant relationship between two variables $\chi 2$ $(2, \mathrm{~N}=384)=4.789, \mathrm{p}=.310$. Moreover, result is confirmed as $\chi 2$ calculated $=4.789$ is less than $\chi 2$ tabulated $(4,0.05)=9.488$. Therefore, this study rejected the proposed $\mathbf{H}_{\mathbf{3}}$ 'The academic performance influence entrepreneurship intention'. The result shows there is no significant relationship between academic performance and career choice after graduation. Thus, it is evident from the finding that entrepreneurship is not merely the last option or an option for the academically weak individual. Asoni (2011) supports the conclusion in stating that formal college education does not play a significant role when it comes to entrepreneurship. Other studies have suggested that higher levels of education might generate 
better opportunities in other sectors and thus, decrease the likelihood of creating the business (Kangasharju \& Pekkala, 2002; Van der Sluis et al., 2004; Wu \& Wu, 2008). However, this study found no relationship between academic score and entrepreneurial intention in Bhutan.

Table 7. Cross tabulation of academic performance and job preference after graduation

\begin{tabular}{|c|c|c|c|c|}
\hline \multirow{2}{*}{ Academic performance } & \multicolumn{3}{|c|}{ Job preference after graduation } & \multirow{2}{*}{ Total } \\
\cline { 2 - 5 } & Civil Servant & Entrepreneur & Corporate employee & \\
\hline High & 37 & 31 & 26 & 94 \\
\hline Average & 81 & 88 & 37 & 206 \\
\hline Low & 30 & 36 & 18 & 84 \\
\hline Total & 148 & 155 & 81 & 384 \\
\hline
\end{tabular}

Table 8. Chi-square Test result of academic performance and job preference after graduation

\begin{tabular}{|l|c|c|c|}
\hline & Value & df & Asymp. Sig (2-sided) \\
\hline Pearson Chi-Square & $4.789^{\mathrm{a}}$ & 4 & .310 \\
\hline Likelihood Ratio & 4.749 & 4 & .314 \\
\hline Linear-by-Linear Association & .075 & 1 & .785 \\
\hline N of Valid Cases & 384 & - & - \\
\hline
\end{tabular}

a. 0 cells $(0.0 \%)$ have expected count less than 5. The minimum expected count is 17.72

\subsection{Job Experience and Entrepreneurship Intentions}

Students were made to indicate part-time jobs they usually did during vacations. As shown in Table 9, 64 students worked in construction, 53 worked in family business, 122 did the internship in various government offices, and 145 did not work any part-time job. The study conducted Chi-square test of independence to determine the relationship between job experiences and entrepreneurial intention. Result in Table 10 shows a significant association $\chi 2(2, \mathrm{~N}=384)=12.346, \mathrm{p}=.015$. The relationship is confirmed as $\chi 2$ calculated $=12.346$ is also greater than $\chi 2$ tabulated $(4,0.05)=9.488$. The study showed more than half of the students $(62.3 \%)$ who worked in the family business are inclined towards entrepreneurship as compared to those who worked in construction (32.8\%), internship (38.5\%), and did not engage in any part-time job (37\%). Thus, the study accepted $\mathbf{H}_{\mathbf{4}}$ 'The job experience in business influence entrepreneurial intention' at 5\% significance level. The finding of this research complements the results of Kolvereid (1996) who noted higher entrepreneurial intention among those with entrepreneurship experiences compared to those without any experience. Moreover, McStay (2008) also who reported that an individual's past business experience influences their decision-making and business performance. This study revealed higher entrepreneurship intentions among students whose parents are the business person and those who engaged in business related part-time job. Similarly, Fatoki (2014) stated that previous exposure to business, role models and networks are important reasons why individuals become entrepreneurs. The result indicated that students who did the 
part-time job in government offices are less likely to start a new business as compared to one who did the business related part-time job. Therefore, it is important for relevant authorities to create the avenue for students to do part-time jobs in business related organizations to boost entrepreneurship culture in Bhutan.

Table 9. Cross tabulation of job experience and job preference after graduation

\begin{tabular}{|l|c|c|c|c|}
\hline \multirow{2}{*}{ Job experience } & \multicolumn{3}{|c|}{ Job preference after graduation } & \multirow{2}{*}{ Total } \\
\cline { 2 - 4 } & Civil servant & Entrepreneur & Corporate & \\
\hline Constructions & 28 & 21 & 15 & 64 \\
\hline Business related internship & 13 & 33 & 7 & 53 \\
\hline Internship in government office & 44 & 47 & 31 & 122 \\
\hline None & 63 & 54 & 28 & 145 \\
\hline Total & 148 & 155 & 81 & 384 \\
\hline
\end{tabular}

Table 10. Chi-square test result of job experience and profession after graduation

\begin{tabular}{|l|c|c|c|}
\hline & Value & df & Asymp. Sig (2-sided) \\
\hline Pearson Chi-Square & $12.346^{\mathrm{a}}$ & 4 & .015 \\
\hline Likelihood Ratio & 12.270 & 4 & .015 \\
\hline Linear-by-Linear Association & .624 & 1 & .429 \\
\hline N of Valid Cases & 239 & & \\
\hline
\end{tabular}

a. 0 cells $(0.0 \%)$ have expected count less than 5. The minimum expected count is 11.75 .

\section{Conclusion}

This study explored the effect of individual factors such as age, the field of study, academic performance, and job experience on entrepreneurial intentions of the undergraduate students in Bhutan. Except for academic performance, the result found age, the field of study, and job experience have a significant influence on student's entrepreneurial intention upon their graduation. Therefore, current findings suggest introducing entrepreneurship educations in the university curriculum and encouraging students to take part-time jobs in business-related organizations. This study did not determine the influence of environmental factors on entrepreneurial intentions, which pave the road for future researchers to conduct an in-depth study on it.

\section{Acknowledgements}

We would like to acknowledge all the students who participated in this study, other individuals who helped to refine this article and particularly to two reviewers for their critical comments.

\section{References}

Asoni, A. (2011). Intelligence, self-confidence and entrepreneurship. IFN Working Paper, No. 
887. http://dx.doi.org/10.2139/ssrn.2050371

Drennan, J., Kennedy, J., \& Renfrow, P. (2005). Impact of childhood experiences on the development of entrepreneurial intentions. The International Journal of Entrepreneurship and Innovation, 6(4), 231-238. https://doi.org/10.5367/000000005775179801

Ekpoh, U. I., \& Edet, A. O. (2011). Entrepreneurship education and career intentions of tertiary education students in Akwa Ibom and Cross River States, Nigeria. International Education Studies, 4(1), 172. http://dx.doi.org/10.5539/ies.v4n1p172

Elder, S., \& Rosas, G. (2015). Global employment trends for youth 2015: Scaling up investments in decent jobs for youth. International Labor Organization. Retrieved from http://hdl.voced.edu.au/10707/381022

Fatoki, O. (2014). The entrepreneurial intention of undergraduate students in South Africa: The influences of entrepreneurship education and previous work experience. Mediterranean Journal of Social Sciences, 5(7), 294. https://doi.org/10.5901/mjss.2014.v5n7p294

Green, F. (2013). Youth entrepreneurship: A background paper for the OECD Centre for Entrepreneurship, SMEs and Local Development. Retrieved from http://www.oecd.org/cfe/leed/youth_bp_finalt. pdf

Henley, A. (2007). Entrepreneurial aspiration and transition into self-employment: Evidence from British longitudinal data. Entrepreneurship \& Regional Development, 19(3), 253-280.

Kangasharju, A., \& Pekkala, S. (2002). The role of education in self-employment success in Finland. Growth and change, 33(2), 216-237. https://doi.org/10.1111/0017-4815.00188

Kew, J., Herrington, M., Litovsky, Y., \& Gale, H. (2013). Generation Entrepreneur? The state of global youth entrepreneurship. Youth Business International and Global Entrepreneurship Monitor.

Kolvereid, L. (1996). Prediction of employment status choice intentions. Entrepreneurship: Theory and Practice, 21(1), 47-58.

Kolvereid, L., \& Moen, Ø. (1997). Entrepreneurship among business graduates: Does a major in entrepreneurship make a difference? Journal of European industrial training, 21(4), 154-160. https://doi.org/10.1108/03090599710171404

McStay, D. (2008). An investigation of undergaduate student self-employment intention and the impact of entrepreneurship education and previous entrepreneurial experience.

Ministry of Labour and Human Resources. (2015). Labour Force Survey Report 2015. Ministry of Labour and Human Resources.

Noel, T. (2001). Effects of entrepreneurial education on intent to open a business. Frontiers of Entrepreneurship Research. Paper presented at the Babson Conference Proceedings, Babson College.

Owusu-Ansah, W. A. (2004). The impact of entrepreneurship education on career intentions 
and aspiration of tertiary students in Ghana. Paper presented at the A paper presented at the 49th World Conference of International Council for Small Business, 20th to 23rd June.

Reynolds, P. D. (2005). Understanding business creation: Serendipity and scope in two decades of business creation studies. Small Business Economics, 24(4), 359-364. https://doi.org/10.1007/s11187-005-0692-x

Salami, C. (2011). Entrepreneurial interventionism and challenges of youth unemployment in Nigeria. Global Journal of Management and Business Research, 11(7). https://doi.org/10.17406/GJMBR

Schoof, U. (2006). Stimulating Youth Entrepreneurship: Barriers and incentives to enterprise start-ups by young people. International Labour Organization.

Sharma, L., \& Madan, P. (2014). Effect of individual factors on youth entrepreneurship-a study of Uttarakhand state, India. Journal of Global Entrepreneurship Research, 4(1), 3. https://doi.org/10.1186/2251-7316-2-3

Stangler, D., \& Spulber, D. (2013). The age of the entrepreneur: Demographics and entrepreneurship. Paper presented at the Summit March, Menlo Park, USA.

Utha, K., Rinchen, S., Gurung, B., Gurung, G., Rabgay, T., \& Dorji, C. (2016). Entrepreneurship Education in Bhutan: Perception, Culture and Challenges. World Journal of Educational Research, 3(2), 460. https://doi.org/10.22158/wjer.v3n2p460

Van der Sluis, J., van Praag, M., \& Vijverberg, W. P. (2004). Education and entrepreneurship in industrialized countries: A meta-analysis.

Wang, W., Lu, W., \& Millington, J. K. (2011). Determinants of entrepreneurial intention among college students in China and USA. Journal of Global Entrepreneurship Research, $1(1), 35-44$.

Wilson, F., Kickul, J., \& Marlino, D. (2007). Gender, entrepreneurial self - efficacy, and entrepreneurial career intentions: implications for entrepreneurship education. Entrepreneurship theory and practice, 31(3), 387-406. https://doi.org/10.1111/j.1540-6520.2007.00179.x

$\mathrm{Wu}$, S., \& Wu, L. (2008). The impact of higher education on entrepreneurial intentions of university students in China. Journal of Small Business and Enterprise Development, 15(4), 752-774. https://doi.org/10.1108/14626000810917843

\section{Copyright Disclaimer}

Copyright for this article is retained by the author(s), with first publication rights granted to the journal.

This is an open-access article distributed under the terms and conditions of the Creative Commons Attribution license (http://creativecommons.org/licenses/by/3.0/). 